\title{
On the Issue of a Conceptual Model of Legal Regulation of Agricultural Activities in the Arctic zone of the Russian Federation
}

\author{
Natalia Voronina ${ }^{1}$, and Zhanna Shnorr ${ }^{2, *}$ \\ ${ }^{1}$ Kutafin Moscow State Law University (MSAL), 125993 Moscow, Russia \\ ${ }^{2}$ Novosibirsk State University of Economics and Management NSUEM, 630099 Novosibirsk, Russia
}

\begin{abstract}
Pursuant to the UN Millennium Goals, approved in 2000, hunger should be eradicated in the 21 st century, while addressing environmental problems that have accumulated over the past hundred years. One of the global environmental problems is climate change. Areas with the most vulnerable ecological system, in particular, the Arctic, are under a special blow. The Arctic zone of the Russian Federation (hereinafter - the RF AZ) is the territory of the national interests of our country. These are geopolitical, military, environmental, demographic and other interests. One of the current economic problems of the RF AZ is low food self-sufficiency. Therefore, one of the tasks is the growth of agricultural production. The situation is complicated by the fact that climatic changes negatively affect the food base of reindeer, there is a decrease in the volume of aquatic biological resources, and land resources are being depleted. The experience of foreign subarctic states shows that it is possible to use genetic technologies in agricultural activities. But at the same time, agricultural technologies should be safe for the environment. Therefore, the current task is the legislative definition of legal requirements, including environmental ones, for agricultural activities in the RF AZ. The purpose of the article is to define a conceptual model of legal regulation of agricultural activities in the RF AZ. By means of the methods of comparative analysis, legal hermeneutics and legal modeling, the content and form of the conceptual model of legal regulation of agricultural activities in the RF AZ have been formulated.
\end{abstract}

\section{Introduction}

In the Food Security Doctrine, food security refers to the state of the country's social-andeconomic development, which ensures both the food independence of our country and the right of citizens to physical and economic access to food.

The problem of ensuring food security is especially relevant for a number of Russian regions due to their "economic and geographical location and development". The Arctic is a region in which complete food self-sufficiency is unattainable due to unfavorable conditions for agriculture [1]. A number of factors may be identified that adversely affect the state of Arctic agriculture: difficult natural conditions, weak infrastructure, an insignificant level of

\footnotetext{
* Corresponding author: nvoroninamgua@yandex.rul.o
} 
agricultural production, dependence on northern supplies; features of the settlement of residents [2].

The strategic planning documents aimed at the development of the RF AZ, approved by the President of the RF in 2020, note that the goal of the RF AZ economic development is to stimulate local production of agricultural raw materials and food. Herewith, any economic activity in the Arctic, and, consequently, agricultural, should be environmentally safe [3] and consider the interests of indigenous people.

Analysis of the legal regulation of the implementation of agricultural activities, including from the standpoint of environmental and legal requirements, in the RF AZ makes it possible to draw a conclusion about its insufficient nature, gaps and collisions. In the scientific literature, one may see individual publications either on the issues of ensuring the food security of the Arctic by Russian [4, 5] and foreign researchers [6], or on the environmental safety of the RF AZ [7, 8]. Herewith, there is not enough scientific research aimed at comprehensive legal regulation of agricultural activities, including environmental and legal requirements, in the RF AZ, which determines the relevance of the topic. It is necessary to define a conceptual model of legal regulation of agricultural activities in the RF AZ in the conditions of modern environmental and biological hazards and risks, performed including with the use of genomic technologies, on the basis of which proposals will be formulated to enhance the current legislation.

\section{Methods and types}

The study was performed on the basis of a number of methods: comparative analysis, legal hermeneutics, legal modeling. A comparative analysis of scientific literature, current Russian legislation, and international documents made it possible to identify environmental and legal problems of agricultural activities in the RF AZ, to assess the risks and dangers. Among them, the lack of legal regulation, legal conflicts, etc. The method of legal hermeneutics made it possible to interpret the current legal norms in order to determine the most effective environmental and legal requirements for the implementation of agricultural activities in the Arctic. The method of legal modeling made it possible to determine the content and form of the model of legal regulation of agricultural activities in the RF AZ.

\section{Results and Discussion}

By the conceptual model of legal regulation, we mean a set of legal signs and characteristics of impact on the behavior of participants in public relations by means of interrelated legal means, methods and ways aimed at effectively achieving goals through the implementation of tasks [9]. On the inside (content) is a system of legal signs and characteristics of impact on public relations, on the outside (form) - a set of normative legal acts governing public relations.

First of all, it is necessary to define the concept of agricultural activity. The current legislation of the Russian Federation does not contain its definition. Summarizing domestic and foreign experience, we construe the agricultural activity as plant growing, animal husbandry, beekeeping, aquaculture, fishing and other activities that depend on climatic conditions, properties of land and other natural resources and meet the criteria determined by the Ministry of Agriculture of Russia.

Agricultural activities are characterized by: the use of natural resources (primarily agricultural land), consideration of biological factors of plants and animals, direct dependence on climatic conditions, seasonality [10]. But now it is also characterized by low competitiveness, inertia, unemployment, underdeveloped infrastructure [11]. All these 
factors in the Arctic are acquiring an even greater negative impact on agricultural activities. In addition, based on the direction of economic activity, these territories are classified as raw materials, which makes agricultural activities only an auxiliary type.

The State Program for the Development of Agriculture and the Regulation of Agricultural Products, Raw Materials and Food Markets provides for an increase in the number of reindeer and marals. Herewith, a strategic task was set - the growth of the use of genomic technologies, including in agriculture. In the RF AZ, this issue has a direct relationship with climatic changes, which leads to an increase in the risks of agricultural activities [12]. As a result, it is required to develop breeds of farm animals, varieties of agricultural plants and aquaculture that are resistant to unfavorable ecology, but have a high nutritional value [13, 14]. For agricultural producers, this is an increase in the volume of products produced and profits. This will allow, over time, to modernize the industrial infrastructure of the RF AZ agroindustrial complex and move to innovative agricultural activities.

However, one should not forget about the possible risks of the implementation of genomic technologies for the Arctic ecosystem and public health. Therefore, "on the one hand, it is necessary to expand the conduct of scientific ... research and development, on the other, to try to predict and mitigate the environmental risks" [15]. It is required regulatory to determine the list of environmental and legal risks (threats) in the implementation of genomic technologies in agricultural activities. The main threats (risks) are the risk of environmental degradation to such a state that it will be impossible for humans to exist as a biological species in the implementation of nature management; the risk of a decrease in the resource potential of the RF AZ; the risk of human diseases; the risk of changing the gene pool of the territory; biodiversity loss risk [16]. These risks make it possible to presume a possible temporary ban on the use of genomic technologies in the RF AZ pending an empirical test of the technologies for their biological and genetic safety [17].

Herewith, one should not ignore the opinion of a number of scientists who believe that the RF AZ may be a zone of organic agriculture. Despite the fact that in the Russian literature the issues of introducing organic agriculture have been studied in some detail [18], nothing is said about the possibilities of organic agriculture in the Arctic. Meanwhile, pursuant to the experience of Finland, the production of environmentally friendly products may also ensure their export.

The main types of agricultural activities in the Arctic are at the same time the traditional types of farming of the indigenous peoples (hereinafter - the IP) living there. The legal regulation of their implementation should also consider the right of these peoples to a traditional way of life and management.

In our country, over the past decades, a system of legal norms has been developing aimed at ensuring the rights of IP. This is Article 69 of the Constitution of the Russian Federation, which provides that the rights of indigenous peoples are guaranteed pursuant to generally recognized principles and norms of international law and international treaties, as well as the cultural identity of peoples and ethnic communities of the Russian Federation is protected and the preservation of ethnocultural and linguistic diversity is guaranteed.

Constitutional norms are implemented in a number of federal laws, the basic of which is the Federal Law of April 30, 1999 No. 82-FZ "On guarantees of the rights of the indigenous peoples of the Russian Federation" (hereinafter - the Law on guarantees). IP have a number of rights in the field of natural resource use and traditional economic activity: free use of land resources in places of traditional residence and traditional economic activity, common minerals (hereinafter referred to as the $\mathrm{CM}$ ), participation in control over the use of land and $\mathrm{CM}$, compliance with environmental legislation in industrial use land and natural resources, construction and reconstruction of economic facilities, obtaining funds necessary for the social-and-economic and cultural development of small peoples, participation in the preparation and adoption of managerial decisions in the field of traditional economic 
activities, environmental and ethnological expertise, to compensate for losses caused them as a result of damage to the original habitat of small peoples by economic activities, etc.

In more detail, the implementation of the traditional use of natural resources by indigenous peoples is regulated by the Federal Law of May 7, 2001 No. 49-FZ "On the Territories of Traditional Nature Use of the Indigenous Minorities of the North, Siberia and the Far East of the Russian Federation" (hereinafter - the Law on Territories of Traditional Nature Use).

The traditional use of natural resources of the IP of the Russian Federation is understood as "historically established and ensuring sustainable use of natural resources, the use of objects of flora and fauna, other natural resources by the indigenous peoples of the North, Siberia and the Far East of the Russian Federation" (Article 1 of the Law on the Territories of Traditional Nature Use).

The territories of traditional nature use of IP are subdivided into territories of federal, regional and local significance and are formed on the basis of the decision of the relevant state authorities and local self-government bodies upon the appeal of the indigenous peoples and their communities. Currently, only regional and local territories of traditional nature management have been created. There are a number of problems. First of all, this is the slow formation of such territories, as well as the lack of a clear position of the legislator regarding the determination of the legal regime of these territories [19]. Therefore, the direction of modernization of the Law on Territories of Traditional Nature Use is to enhance the mechanism for the formation, protection, use and abolition of territories of traditional nature use of IP, as well as to determine the algorithm for creating model territories of traditional nature use of federal significance.

The territories of traditional nature use of the IP may be subdivided into the following parts: settlements (stationary dwellings, camps, reindeer herders, hunters, fishermen), land and water areas (reindeer pastures, hunting and other lands, sea areas for fishing, collecting wild plants), objects of historical and cultural heritage (places of worship, places of ancient settlements and burial places of ancestors).

Legislation on certain types of natural resources and nature management sufficiently regulates the right of IP to use natural resources in order to preserve their traditional way of life and economic management, mediating international norms aimed at protecting the interests of IP. But these normative legal acts are not of a systemic nature, contain gaps and conflicts. For instance, in the Law on Guarantees, there is no conceptual understanding of the concepts of "traditional economic activity", "personal needs" and "personal consumption" [20]. Implementation of the Law on Territories of Traditional Natural Resource Use "contradicts the purpose of its creation". By now, a number of vital norms have been withdrawn from the federal laws on indigenous peoples... The "legal fog" contributes to the fact that all court cases on the formation of federal territory of traditional nature management have been lost... The legal framework for the creation of the territory of traditional nature management and the enhancement of the living conditions of the northern aborigines is not working in full force" [21].

The IP are represented by their communities. The legal status of IP' communities is regulated by the Federal Law dated July 20, 2000 No. 104-FZ "On the General Principles of Organization of Communities of Indigenous Minorities of the North, Siberia and the Far East of the Russian Federation" (hereinafter - the Law on Communities). An IP community is understood as "a form of self-organization of persons belonging to small peoples and united by consanguinity (family, clan) and (or) territorial neighbors, created in order to protect their ancestral habitat, preserve and develop traditional lifestyles, economic activities, crafts and culture" (Article 1 of the Law on Communities).

The Convention on Indigenous Peoples (art. 33) obliges national authorities to adopt programs aimed at ensuring the rights of IP. In the Russian Federation, these include strategic 
planning documents. Decree of the President of the Russian Federation dated December 19, 2012 No. 1666 "On the Strategy of the State National Policy of the Russian Federation for the Period up to 2025 " determines that the observance of the rights of IP is a priority, and the sustainable economic, social and cultural development of IP, the protection of the original habitat and traditional way of life - the principle of state nationality policy. Herewith, the implementation of the economic rights of IP requires their adaptation to new economic conditions, and participation in managerial decision-making requires the enhancement of the public administration system. State support for the traditional activities of IP is needed as well. Therefore, Article 28 of the Federal Law dated July 13, 2020 No. 193-FZ "On state support for entrepreneurial activity in the Arctic zone of the Russian Federation" enshrines a rule aimed at state support for these types of activities. Financing of state support for agricultural activities of IP is envisaged in the Decree of the Government of the Russian Federation dated March 30, 2021 No. 484 "On approval of the state program of the Russian Federation" Social and economic development of the Arctic zone of the Russian Federation".

Legislation provides for the traditional types of agricultural activities of the AZ RF IP: reindeer breeding, horse breeding, sheep breeding, dog breeding, animal husbandry, beekeeping, beekeeping, fishing, agriculture, etc. The risk factors for the development of traditional economic activity of IP are generalized, among them are the climatic changes, an increase in anthropogenic load in places of traditional residence of IP, significant costs in performing economic activities, and a low level of infrastructure development. Their minimization should be aimed at modern legal regulation of the implementation of traditional economic activities, including in the field of agriculture. Therefore, as directions for improving the legal regulation of public relations in this area: clarification of places of traditional residence and traditional economic activities of IP, as well as the list of types of their traditional economic activities; establishing the specifics of regulating the circulation of medicinal raw materials obtained in the framework of the implementation of reindeer husbandry; determination of the specifics of acquiring the status of a producer of agricultural products by the IP communities; supplementing types of agricultural products with types of products of marine animal hunting. But the implementation of traditional agricultural activities of IP should also be as safe as possible from an environmental and biological point of view.

\section{Conclusions}

In conclusion, it should be noted that the enhancement of legal regulation of agricultural activities in the Arctic zone of the Russian Federation should be performed on the basis of a conceptual model of legal regulation. From the inside, it is a system of the main features and characteristics of the legal impact on internal and external relations for the production, storage, transportation, sale of agricultural products in the RF AZ, performed in compliance with the requirements established by the current legislation, aimed at ensuring food, environmental and biological safety. On the outside, this is a set of normative legal acts aimed at regulating public relations in the field of production, storage, transportation, and sale of agricultural products by agricultural producers of the RF AZ. This set is made up of political, legal and regulatory legal acts regulating the implementation of agricultural activities, the development of the RF AZ, the provision of food, environmental and biological security, state support for agriculture and the traditional activities of IP, which should be systemic and correlated with each other. 


\section{References}

1. V.A. Ivanov, E.V. Ivanova, Arktika: ekologiya i ekonomika, 6, 18 (2017)

2. O.I. Gerasimov, E.V. Rytova, Molodezhnyj nauchnyj vestnik, 10 (2016)

3. S.A. Bogolyubov, I.O. Krasnova, Aktual'nye problemy rossijskogo prava, 6, 178 (2018)

4. L.V. Voronina, M.G. Yurkevich, To cite this article: 2020, 539, 012056 (2020)

5. N. P. Voronina, Earth and Environmental Science, 263, 012065 (2019)

6. H. Kamrul, R. Dele, Shaun Cormier Food security governance in the Arctic-Barents region (Springer International Publishing, 2018)

7. N. P. Voronina, Economic and Social Development 54 th International Scientific Conference on Economic and Social Development Development, 360 (2020)

8. N. P. Voronina, The Case of Genomic Technologies, 670, 012050 (2021)

9. N.P. Voronina, Agrarnoe i zemel'noe pravo, 7, 17 (2020)

10. Agrarnoe pravo (Prospekt, 2010)

11. S.A. Bogolyubov, ZHurnal rossijskogo prava, 9, 47 (2007)

12. S.A. Bogolyubov, I.O. Krasnova, Aktual'nye problemy rossijskogo prava, 6, 178 (2018)

13. I.P. Voronina, Pravo i sovremennye tekhnologii v medicine (Prospekt, 2019).

14. M. I. Selionova, A. Ajbazov, Genomnye tekhnologii v selekcii sel'skohozyajstvennyh zhivotnyh, https://cyberleninka.ru

15. N.O. Vedysheva, Pravo i sovremennye tekhnologii v medicine (Prospekt, 2019)

16. V. B. Agafonov, Pravo i sovremennye tekhnologii v medicine (Prospekt, 2019)

17. N. G. ZHavoronkova, V.B. Agafonov, Lex Russica, 6, 69 (2019)

18. B.A. Voronin, Agrarnyj vestnik Urala, 9, 80 (2013)

19. R. A. Toriya, Biznes v zakone. Ekonomiko-yuridicheskij zhurnal, 1, 208 (2016)

20. Sever i severyane. Sovremennoe polozhenie korennyh malochislennyh narodov Severa, Sibiri i Dal'nego Vostoka Rossii (IEA RAN, 2012)

21. M.V. Ragulina, Izvestiya Irkutskogo gosudarstvennogo universiteta, 7, 122 (2014) 